\title{
PSMC3IP wt Allele
}

National Cancer Institute

\section{Source}

National Cancer Institute. PSMC3IP wt Allele. NCI Thesaurus. Code C126596.

Human PSMC3IP wild-type allele is located in the vicinity of $17 q 21.2$ and is approximately $6 \mathrm{~kb}$ in length. This allele, which encodes homologous-pairing protein 2 homolog protein, plays a role in both meiosis and transcriptional activation. 